\title{
Factorial experimental design for biobutanol production from oil palm frond (OPF) juice by Clostridium acetobutylicum ATCC 824
}

\author{
Nur Syazana Muhd Nasrah ${ }^{1}$, Mior Ahmad Khushairi Mohd Zahari, Nasratun Masngut ${ }^{1}$, Hidayah Ariffin ${ }^{2}$ \\ ${ }^{I}$ Universiti Malaysia Pahang, Faculty of Chemical Engineering \& Natural Resources, 26300 Gambang, Pahang, \\ Malaysia. ${ }^{2}$ Universiti Putra Malaysia, Faculty of Biotechnology and Biomolecular Sciences, 43400 UPM Serdang, \\ Selangor, Malaysia.Article Info: Submitted on March 20, 2017, Accepted on June 20, 2017.
}

\begin{abstract}
Biobutanol is an alternative energy that can be promising as the future energy source. It can be produced from natural and renewable agriculture wastes such as oil palm frond (OPF) juice by microbes. Clostridium acetobutylicum has the ability to ferment the sugars in OPF juice as carbon source into biobutanol. This research aimed to investigate the effect of independent and interaction factors; initial $\mathrm{pH}$ medium (5-7), inoculum size (1$20 \%)$, initial total sugars concentration $(40-60 \mathrm{~g} / \mathrm{L})$, temperature $\left(32-42^{\circ} \mathrm{C}\right)$ and yeast extract concentration $(1-10$ $\mathrm{g} / \mathrm{L}$ ) on the production of biobutanol from oil palm frond (OPF) juice by $C$. acetobutylicum ATCC 824 using a two level half factorial design which have been developed by the Design Expert Software Version 7.1. Based on the factorial analysis, it was observed that the most significant parameter was yeast extract concentration, which contributes $8.20 \%$, followed by inoculum size and temperature, which were contribute $7.84 \%$ and $7.56 \%$, respectively. The analysis showed the $\mathrm{R}^{2}$ value for the model was 0.9805 and the interaction between inoculum size and temperature gave the highest influenced to the fermentation process with contribution up to $16.31 \%$. From the validation experiments, the experimental values were reasonable close to the predicted values with only $5.87 \%$ and $10.09 \%$ of errors. It confirmed the validity and adequacy of the predicted models. Hence, the data analysis developed from the Design Expert Software could reliably predict biobutanol yields. This study indicated that each of the factors may affect the fermentation process of the biobutanol production.
\end{abstract}

Keywords: Biobutanol; Clostridium acetobutylicum; Oil palm frond Juice; Factorial design.

\section{Introduction}

Due to the fluctuation of oil prices and rising concerns over the environment, the attention to seek alternative, cost-effective and environmentally energy resources is developing among the researchers. Among various alternative fuels, biobutanol has been recognized as a good candidate as a biofuel for its interesting advantages: higher energy content, lower vapor pressure making it safer to use, and lower hygroscopy; thus make it easy to preserve and distribute as it does not absorb water. ${ }^{1}$ Moreover, biobutanol has properties which can be applied in pure form or blended in any concentration with gasoline or diesel, can be used in any automobile engine without modifications and can be converted to valuable chemical compounds such as acrylate, methacrylate esters, glycol ethers and butyl acetate. $^{2}$

Biobutanol can be produced via acetone-butanolethanol (ABE) fermentation from renewable biomass products using several genera of bacteria, particularly Clostridium species in anaerobic conditions. It is an anaerobic, gram-positive, and spore-forming microorganism. It has an ability to produce acetone, butanol, ethanol, as a final product under anaerobic condition, using different carbohydrate sources including monosaccharides, and polysaccharide. $C$. saccharoperbutylacetonicum, C. acetobutylicum, C.beijerinckii, and C. aurantibutyricum are most capable to produce significant amounts of solvents among the other microorganism. ${ }^{3}$ Therefore, in this study $C$. acetobutylicum ATCC 824 has been chosen to produce biobutanol. However, one of the limitations of $\mathrm{ABE}$ fermentation is the cost of substrates, to the extent that the production facilities have even been shut down due to the high price of molasses. ${ }^{4}$ Therefore, the possibility of using abundant and renewable sources of lignocellulosic residues, such as oil palm frond (OPF) waste, as carbon sources for conversion into biobutanol holds great promises. Moreover, OPF is reported as the most abundant oil palm wastes generated by the oil palm industry in most Asian and African countries. Indonesia and Malaysia together generated about 55 million tonnes of OPFs and only about $5 \%$ was utilized in the palm plantation as mulch in 2011 (MPOB). Zahari et al., has demonstrated the potential of OPF juice as a renewable fermentation feedstock for producing one of the fermentation product, poly(3-hydroxybutyrate), by Cupriavidusnecator CCUG 52238T. It was reported 


\section{Chemical Engineering Research Bulletin 19(2017) 36-42}

that the OPF juice contained $76.09 \mathrm{~g} / \mathrm{L}$ of total sugars just by simple pressing the fresh OPF using sugarcane pressing machine. ${ }^{5}$

The aim of this study was to determine the effect of key process parameters (initial $\mathrm{pH}$ medium, incubation temperature, inoculum size, total sugars concentration in OPF juice and yeast extract concentration) on biobutanol production from OPF juice by $C$. acetobutylicum ATCC 824. The study was conducted using a half fractional factorial design (FFD) method and evaluated using Design Expert version 7.1 (StateEase, Inc., Minneapolis, MN).

\section{Materials and Methods}

\section{Clostridium strain and inoculum preparation}

Clostridium acetobutylicum ATCC 824 was obtained from American Type Culture Collection (ATCC) in freeze-dried form and maintained on Reinforced Clostridium Medium (RCM) broth. Spore suspension was prepared by transferring $1 \mathrm{~mL}$ of glycerol stock into $90 \mathrm{~mL}$ RCM for 3 days at $37^{\circ} \mathrm{C}$ under anaerobic conditions. This culture was then transferred on RCM medium with subsequent heat shock for $90 \mathrm{~s}$ in $90^{\circ} \mathrm{C}$ water bath and incubated at $37^{\circ} \mathrm{C}$ for $18-20 \mathrm{hr}$ to be used as inoculum. The inoculum was deemed to be ready for fermentation when the optical density was between 1.5 and 2.0.

\section{Preparation of oil palm frond $(\mathrm{OPF})$ juice}

The oil palm frond (OPF) used was collected from oil palm plantation at FeldaLeparHilir, Kuantan, Pahang and was cut into small size. The juice was prepared by pressing the fresh OPF (without leaves) using sugarcane pressing machine by following the previous method described earlier by Zahari et al. (2012). ${ }^{5}$ Then, the juice was centrifuged at $10,000 \mathrm{rpm}$ for 10 min and filtered to remove the solid particles. The precipitate (pellet) was decanted and the supernatant (OPF juice) was used in the fermentation. OPF juice was then distributed up to the required working volume into $125 \mathrm{~mL}$ serum bottles, sparged with oxygen-free nitrogen gas, sealed and sterilized at $121^{\circ} \mathrm{C}$ for $15 \mathrm{~min}$. It was then mixed with synthetic P2 medium in known proportion to prepare the final fermentation medium. Synthetic P2 medium had the following composition (in $\mathrm{g} / \mathrm{L}$ ): yeast extract, 5; $\mathrm{KH}_{2} \mathrm{PO}_{4}, 0.5 ; \mathrm{K}_{2} \mathrm{HPO}_{4}, 0.5$; para aminobenzoic acid, 0.001 ; thiamin, 0.001 ; biotin, $1 \times 10-5 ; \mathrm{MgSO}_{4} .7 \mathrm{H}_{2} \mathrm{O}$, $0.2 ; \mathrm{MnSO}_{4} .7 \mathrm{H}_{2} \mathrm{O}, 0.01 ; \mathrm{FeSO}_{4} .7 \mathrm{H}_{2} \mathrm{O}, 0.01 ; \mathrm{NaCl}$, 0.01; and ammonium acetate, 2.2 .

\section{Experimental setup}

The fermentation was conducted in $125 \mathrm{~mL}$ serum bottle with different properties depending on the runs, flushed with $\mathrm{N}_{2}$ gas and sterilized at $121^{\circ} \mathrm{C}$ for $15 \mathrm{~min}$. Five (5) factors (total sugars concentration, initial $\mathrm{pH}$ medium, yeast extract concentration and temperature) were studied in their range of value respectively. These parameters were controlled and observed for screening process. $5 \mathrm{~mL}$ of sample were withdrawn at 0 and 144 $\mathrm{hr}$ for analysis of acetone, butanol, ethanol (ABE), organic acids and sugar. The samples were centrifuged at $8,500 \mathrm{rpm}, 4^{\circ} \mathrm{C}$ for $20 \mathrm{~min}$ before analysis.

\section{Design of experiment}

A total of twenty one (21) experiments were performed according to a $2^{5-1}$ fractional factorial design (FFD) with five factors (16 points of the factorial design and 5 centre points). Table 1 presents the variable factors with the coded and actual values for each parameter set for the experiment. Table 2 shows the experimental design and the results of the response variable studied. The experimental design and analysis of data were done using Design Expert version 7.1 (State-Ease, Inc., Minneapolis, MN). All experiments were performed in triplicates and the results were recorded as mean values of the biobutanol yield.

Table 1: Factors applied in $2^{5-1}$ design, the coded levels and actual values.

\begin{tabular}{|l|c|c|c|c|c|}
\hline \multicolumn{1}{|c|}{ Factors } & Symbols & Units & $\begin{array}{c}\text { Low } \\
(-1)\end{array}$ & $\begin{array}{c}\text { Middle } \\
(0)\end{array}$ & $\begin{array}{c}\text { High } \\
(+1)\end{array}$ \\
\hline $\mathrm{pH}$ & $\mathrm{A}$ & - & 5 & 6 & 7 \\
\hline $\begin{array}{l}\text { Total sugars } \\
\text { in OPF juice }\end{array}$ & $\mathrm{B}$ & $\mathrm{g} / \mathrm{L}$ & 40 & 50 & 60 \\
\hline $\begin{array}{l}\text { Inoculum } \\
\text { size }\end{array}$ & $\mathrm{C}$ & $\%$ & 1 & 10.5 & 20 \\
\hline Temperature & $\mathrm{D}$ & ${ }^{\circ} \mathrm{C}$ & 32 & 37 & 42 \\
\hline $\begin{array}{l}\text { Yeast extract } \\
\text { concentration }\end{array}$ & $\mathrm{E}$ & $\mathrm{g} / \mathrm{L}$ & 1 & 5.5 & 10 \\
\hline
\end{tabular}

\section{Analytical procedures}

The samples of fermentation were filtered through $0.02 \mu \mathrm{m}$ nylon syringe filter and injected into vials. The products including solvents and acids were analyzed by gas chromatography (Agilent Technologies, 6890N network GC system). A microliter of the sample was injected into a $30 \mathrm{~m} \times 0.32 \mathrm{~mm} \times 0.5 \mu \mathrm{m}$ HPINNOWAX capillary column at $250^{\circ} \mathrm{C}$. The column carrier was helium, $40 \mathrm{~cm} / \mathrm{sec}, 11.7 \mathrm{psi}\left(60^{\circ} \mathrm{C}\right)$ with 2.5 $\mathrm{mL} / \mathrm{min}$ constant flow. A flame ionization detector (FID) at $275^{\circ} \mathrm{C}$ was used for signal detection. Glucose, sucrose, and fructose were determined by HPLC(Agilent; 1200) with Rezex ROA - organic acid $\mathrm{H}+(8 \%)$ column (Phenomenex) $(300 \times 7.80 \mathrm{~mm})$ with a flow rate of $0.5 \mathrm{~mL} / \mathrm{min}$ and RI detector at $30^{\circ} \mathrm{C}$. The mobile phase consists of $0.005 \quad \mathrm{M} \quad \mathrm{H}_{2} \mathrm{SO}_{4}$, recommended for the column used. 


\section{Chemical Engineering Research Bulletin 19(2017) 36-42}

Table 2: Experimental design and results for response variable studied.

\begin{tabular}{|c|c|c|c|c|c|c|}
\hline \multirow[b]{2}{*}{ Run } & \multicolumn{5}{|c|}{ Independent variables } & \multirow{2}{*}{$\begin{array}{c}\text { Res } \\
\text { ponse } \\
\text { Biobu } \\
\text { tanol } \\
\text { yield } \\
(\mathrm{g} / \mathrm{g})\end{array}$} \\
\hline & $\mathrm{pH}$ & $\begin{array}{c}\text { Total } \\
\text { sugars } \\
\text { in } \\
\text { OPF } \\
\text { juice } \\
(\mathrm{g} / \mathrm{L})\end{array}$ & $\begin{array}{l}\text { Ino } \\
\text { culum } \\
\text { size } \\
(\%)\end{array}$ & $\begin{array}{c}\text { Tempe } \\
\text { rature } \\
\left({ }^{\circ} \mathrm{C}\right)\end{array}$ & $\begin{array}{c}\text { Yeast } \\
\text { extract } \\
(\mathrm{g} / \mathrm{L})\end{array}$ & \\
\hline 1 & 6 & 50 & 10.5 & 7 & 5.5 & 0.2564 \\
\hline 2 & 7 & 60 & 20 & 32 & & 0.2143 \\
\hline 3 & 5 & 40 & 20 & 32 & & .2206 \\
\hline 4 & 7 & 40 & 1 & 42 & 10 & 0.1862 \\
\hline 5 & 7 & 40 & 20 & 4 & 1 & .0478 \\
\hline 6 & 5 & 60 & 1 & 3 & & .0065 \\
\hline 7 & 7 & 40 & 20 & 32 & 10 & .2049 \\
\hline 8 & 5 & 40 & 20 & 42 & 10 & 0.0969 \\
\hline 9 & 7 & 40 & 1 & 32 & 1 & 0.0154 \\
\hline 10 & 6 & 50 & 10.5 & 3 & 5.5 & 0.2414 \\
\hline 11 & 5 & 40 & 1 & 4 & 1 & 0.0176 \\
\hline 12 & 7 & 60 & 1 & 42 & 1 & 0.0057 \\
\hline 13 & 6 & 50 & 10.5 & 37 & 5.5 & 0.2930 \\
\hline 14 & 5 & 60 & 20 & 42 & 1 & 0.0397 \\
\hline 15 & 5 & 60 & 1 & 4 & 10 & 0.1368 \\
\hline 16 & 6 & 50 & 10.5 & 3 & 5.5 & 0.2506 \\
\hline 17 & 7 & 60 & 20 & 42 & 10 & 0.0474 \\
\hline 18 & 7 & 60 & 1 & 32 & 10 & 0.0287 \\
\hline 19 & 6 & 50 & 10.5 & 37 & 5.5 & 0.2829 \\
\hline 20 & 5 & 40 & 1 & 32 & 10 & 0.1765 \\
\hline 21 & 5 & 60 & 20 & 32 & 10 & 0.2194 \\
\hline
\end{tabular}

\section{Results and Discussion}

\section{Screening of factors affecting biobutanol production}

The production of biobutanol by $C$. acetobutylicum from OPF juice was performed as shown in Table 2. As can be observed, twenty one fermentation runs were carried out with different levels of initial $\mathrm{pH}$, total sugars in OPF juice, inoculum size, temperature and yeast extract concentration according to the design generated. As can be seen, runs 13, 19, and 1 showed the highest biobutanol production with the value as high as $0.2930 \mathrm{~g} / \mathrm{g}, \quad 0.2829 \mathrm{~g} / \mathrm{g}$, and $0.2564 \mathrm{~g} / \mathrm{g}$, respectively. All these three runs were at center points condition where the $\mathrm{pH}$ value of 6 , total sugars $50 \mathrm{~g} / \mathrm{L}$, temperature $37^{\circ} \mathrm{C}$, inoculum size $10.5 \%$ and yeast extract $5.5 \mathrm{~g} / \mathrm{L}$. The lowest biobutanol yield for run 12 can be interpreted by the low percentage of inoculum size of $1 \%$ and too high incubation temperature at $42^{\circ} \mathrm{C}$. The Clostridial cells cannot tolerate and grow at high temperature. The regression model for independent variables in terms of coded factors as shown in equation given below:
Biobutanol yield $=0.10-0.010 \mathrm{~A}-0.017 \mathrm{~B}+0.032 \mathrm{C}-$ $0.032 \mathrm{D}+0.033 \mathrm{E}+\left(9.737 \times 10^{-3}\right) \mathrm{AD}-0.010 \mathrm{AE}+$ $0.011 \mathrm{BC}-0.012 \mathrm{BE}-0.047 \mathrm{CD}-0.027 \mathrm{CE}+0.011 \mathrm{DE}$

Where $\mathrm{A}$ is the $\mathrm{pH}, \mathrm{B}, \mathrm{C}, \mathrm{D}$ and $\mathrm{E}$ are the total sugars in $\mathrm{OPF}$ juice, inoculum size, temperature and yeast extract concentration, respectively. A, B, C, D, and E are referred as the main effect while $\mathrm{AD}, \mathrm{AE}, \mathrm{BC}, \mathrm{BE}$, $\mathrm{CD}, \mathrm{CE}$, and $\mathrm{DE}$ are the interaction effect.

\section{Analysis of variance (ANOVA)}

The statistical significance was evaluated using the statistical test for analysis of variance (ANOVA) as shown in Table 3. As can be seen, calculated model's $F$ value of 29.32 with a probability value (Prob $>F$ ) of $<0.0001$ suggest that the model was significant and fitted well to the experimental data $(\mathrm{P}<0.05)$. The lack of fit is a measure of the failure of a model to represent data in the experimental domain at which data points were not included in the regression model or variations in the models cannot be accounted by random error. If there is a significant lack of fit, the response is not fitted. ${ }^{6}$ As shown in Table 3, the F value for lack of fit with a value of 0.21 and a probability value of 0.8871 implied that lack of fit was insignificant and hence the model was valid for further studies.

\section{Main effects analysis}

From Table 4, it is shown that parameter E (yeast extract concentration) contributes the most to the production of biobutanol as much as $8.20 \%$. It has been reported that with the addition of yeast extract can increase the production of biobutanol by $C$. acetobutylicum DSM 1731 as high as $26 \%{ }^{7} C$. acetobutylicum was able to consume the wide range of yeast extract concentration for higher butanol production, but at too high yeast extract concentration, the butanol yield can be decreased. It is because of the growth of cells were stimulated by the yeast extract, but reduced the tendency to produce the solvents. ${ }^{8}$ Inoculum size shows as the second factor that contributes to the biobutanol production in this study with the percentage of $7.84 \%$.

In this study, the fermentation was performed at different inoculum sizes at $1 \%(\mathrm{v} / \mathrm{v})$ and $20 \%(\mathrm{v} / \mathrm{v})$ with the center point of $10.5 \%(\mathrm{v} / \mathrm{v})$ of inoculum. Shukor et al. (2014) reported that when there is an increasing in inoculum size, the biobutanol production in $\mathrm{ABE}$ fermentation was also increased. This is due to the fact that Clostridial cells decreases the lag phase of growth which improves the microbial cell growth to enhance the solventogenesis phase where the butanol produced. ${ }^{6} \mathrm{~A}$ similar pattern was reported by $\mathrm{Al}$ Shorgani et al. (2015) who studied the production of butanol by Clostridium saccharoperbutylacetonicum N1-4 (ATCC 13564) using palm oil mill effluent. They observed that the increased in inoculum size from $5 \%$ 


\section{Chemical Engineering Research Bulletin 19(2017) 36-42}

to $20 \%$ resulted in an enhanced butanol concentration up to $0.76 \mathrm{~g} / \mathrm{L}$.

Table 3: ANOVA analysis for $2^{5-1}$ fractional factorial design (FFD).

\begin{tabular}{|c|c|c|c|c|c|c|}
\hline Source & $\begin{array}{l}\text { Sum of } \\
\text { squares }\end{array}$ & $\mathrm{df}$ & $\begin{array}{l}\text { Mean } \\
\text { square }\end{array}$ & $\begin{array}{c}\mathrm{F} \\
\text { value }\end{array}$ & $\begin{array}{l}\text { p-value } \\
\text { Prob }>F\end{array}$ & \\
\hline Model & 0.11 & 12 & $\begin{array}{c}9.396 \mathrm{x} \\
10^{-3}\end{array}$ & 29.32 & $<0.0001$ & $\begin{array}{c}\text { Sig } \\
\text { ni } \\
\text { fi } \\
\text { cant }\end{array}$ \\
\hline$A-p H$ & $\begin{array}{c}1.673 \mathrm{x} \\
10^{-3}\end{array}$ & 1 & $\begin{array}{c}1.673 \mathrm{x} \\
10^{-3}\end{array}$ & 5.22 & 0.0563 & \\
\hline $\begin{array}{c}B- \\
\text { Total } \\
\text { sugars } \\
\text { in } \\
\text { OPF } \\
\text { juice }\end{array}$ & $\begin{array}{c}4.469 \mathrm{x} \\
10^{-3}\end{array}$ & 1 & $\begin{array}{c}4.469 \mathrm{x} \\
10^{-3}\end{array}$ & 13.94 & 0.0073 & \\
\hline $\begin{array}{l}\text { C-Ino } \\
\text { culum } \\
\text { size }\end{array}$ & 0.017 & 1 & 0.017 & 52.25 & 0.0002 & \\
\hline $\begin{array}{l}D- \\
\text { Tempe } \\
\text { rature }\end{array}$ & 0.016 & 1 & 0.016 & 50.37 & 0.0002 & \\
\hline $\begin{array}{c}E- \\
\text { Yeast } \\
\text { extract } \\
\text { concen } \\
\text { tration }\end{array}$ & 0.018 & 1 & 0.018 & 54.61 & 0.0002 & \\
\hline$A D$ & $\begin{array}{c}1.517 \mathrm{x} \\
10^{-3}\end{array}$ & 1 & $\begin{array}{c}1.517 \mathrm{x} \\
10^{-3}\end{array}$ & 4.73 & 0.0661 & \\
\hline$A E$ & $\begin{array}{c}1.624 \mathrm{x} \\
10^{-3}\end{array}$ & 1 & $\begin{array}{c}1.624 \mathrm{x} \\
10^{-3}\end{array}$ & 5.07 & 0.0591 & \\
\hline$B C$ & $\begin{array}{c}1.777 x \\
10^{-3}\end{array}$ & 1 & $\begin{array}{c}1.777 \mathrm{x} \\
10^{-3}\end{array}$ & 5.54 & 0.0508 & \\
\hline$B E$ & $\begin{array}{c}2.426 \mathrm{x} \\
10^{-3}\end{array}$ & 1 & $\begin{array}{c}2.426 \mathrm{x} \\
10^{-3}\end{array}$ & 7.57 & 0.0285 & \\
\hline$C D$ & 0.035 & 1 & 0.035 & 108.7 & $<0.0001$ & \\
\hline$C E$ & 0.012 & 1 & 0.012 & 37.21 & 0.0005 & \\
\hline$D E$ & $\begin{array}{c}2.111 \mathrm{x} \\
10^{-3}\end{array}$ & 1 & $\begin{array}{c}2.111 \mathrm{x} \\
10^{-3}\end{array}$ & 6.59 & 0.0372 & \\
\hline $\begin{array}{l}\text { Curva } \\
\text { ture }\end{array}$ & 0.099 & 1 & 0.099 & 307.48 & $<0.0001$ & $\begin{array}{c}\text { Sig } \\
\text { ni } \\
\text { fi } \\
\text { cant }\end{array}$ \\
\hline $\begin{array}{l}\text { Resi } \\
\text { dual }\end{array}$ & $\begin{array}{c}2.243 \mathrm{x} \\
10^{-3}\end{array}$ & 7 & $\begin{array}{c}3.205 \mathrm{x} \\
10^{-4}\end{array}$ & & & \\
\hline $\begin{array}{l}\text { Lack } \\
\text { of fit }\end{array}$ & $\begin{array}{c}3.009 \mathrm{x} \\
10^{-4}\end{array}$ & 3 & $\begin{array}{c}1.003 \mathrm{x} \\
10^{-4}\end{array}$ & 0.21 & 0.8871 & $\begin{array}{c}\text { Not } \\
\text { sig } \\
\text { ni } \\
\text { fi } \\
\text { cant }\end{array}$ \\
\hline $\begin{array}{l}\text { Pure } \\
\text { error }\end{array}$ & $\begin{array}{c}1.943 \mathrm{x} \\
10^{-3}\end{array}$ & 4 & $\begin{array}{c}4.856 \mathrm{x} \\
10^{-4}\end{array}$ & & & \\
\hline $\begin{array}{l}\text { Cor } \\
\text { Total }\end{array}$ & 0.21 & 20 & & & & \\
\hline
\end{tabular}

Table 4: The percentage contribution of each main factors and their interaction.

\begin{tabular}{|c|c|}
\hline Effect list & Contribution (\%) \\
\hline A-pH & 0.78 \\
\hline $\begin{array}{c}\text { B-Total sugars in OPF } \\
\text { juice }\end{array}$ & 2.09 \\
\hline C-Inoculum size & 7.84 \\
\hline D-Temperature & 7.56 \\
\hline $\begin{array}{c}\text { E-Yeast extract } \\
\text { concentration }\end{array}$ & 8.20 \\
\hline AB & 0.07 \\
\hline AC & 0.045 \\
\hline AD & 0.71 \\
\hline AE & 0.76 \\
\hline BC & 0.83 \\
\hline BD & 0.026 \\
\hline BE & 1.14 \\
\hline CD & 16.31 \\
\hline CE & 5.58 \\
\hline DE & 0.99 \\
\hline
\end{tabular}

However, the optimum inoculum size is varied depending on the microorganism and substrate used. As shown in Table 2, the highest butanol yield was achieved at inoculum size $10.5 \%$ compare to $20 \%$ with $0.2930 \mathrm{~g} / \mathrm{g}$. Meanwhile, studies performed by Ranjan et al. (2013) revealed that the maximum butanol production by $C$. acetobutylicum MTCC 481 from rice straw hydrolysate was achieved at an optimum inoculum size of $5 \% .{ }^{10}$ On the other hand, the production of butanol by $C$. acetobutylicum from oil palm decanter cake hydrolysate was investigated by Razak et al. (2013) found the optimum inoculum size of $16.2 \% .^{8}$ This shows that increasing the inoculum size higher than critical level had no important effect on the microbial growth and cell activity which will contribute to the production of butanol. ${ }^{10}$

Based on the ANOVA, temperature contributes as much as $7.56 \%$ on the effect of biobutanol production from OPF juice. One possible explanation was might be due to the fact that $C$. acetobutylicum will lose the ability to produce solvents at high or low temperature because it affects the enzymatic pathway in both acidegonesis and solventogenesis pathways. The cells could not convert the substrate into acids and from acids to solvents. ${ }^{11}$

The least effective factors were the total sugars concentration in OPF juice and initial $\mathrm{pH}$ medium with the values of $2.09 \%$ and $0.78 \%$, respectively. Production of biobutanol in fermentation process is by the conversion of sugar in OPF juice such as glucose, fructose and sucrose into organic acids and the acids were converted into butanol. At low concentration of sugar, the production relatively low because of the law of mass action. Meanwhile at high concentration of sugars, there was a substrate inhibition through $\mathrm{pH}$ 


\section{Chemical Engineering Research Bulletin 19(2017) 36-42}

depletion because the forming of acids in acidogenesis stage increase. ${ }^{4,12}$ In this study, total sugars concentration range was used at $40 \mathrm{~g} / \mathrm{L}$ and $60 \mathrm{~g} / \mathrm{L}$. That is the reason for the result has shown total sugars less affect the fermentation itself. The least effective factors is $\mathrm{pH}$ since as stated in Table 1, the values of $\mathrm{pH}$ studied in this experiment are 5 and 7. Previous reports have shown that the optimum initial $\mathrm{pH}$ value was 5.0-6.5. ${ }^{4}$

\section{Interaction between factors}

Beside the main factors, there are also interaction effects that play important role in the production of biobutanol by $C$. acetobutylicum. There are ten interactions discovered in this study as shown in Table 4. The highest percentage interaction is between factor $\mathrm{C}$, inoculum size and factor $\mathrm{D}$, temperature with $16.31 \%$. The other two high values of interaction are between $\mathrm{C}$, inoculum size with factor $\mathrm{E}$, yeast extract concentration and factor $\mathrm{B}$, total sugars in OPF juice with factor $\mathrm{E}$, yeast extract concentration with value $5.58 \%$ and $1.14 \%$, respectively. The other interactions with low percentage of contribution can be ignored since they give very low effect towards the fermentation process.

Figure 1 shows there is an interaction between inoculum size and temperature. As can be seen, biobutanol yield was increase when the inoculum size was increased with the incubation temperature was set at $32^{\circ} \mathrm{C}$. At $42^{\circ} \mathrm{C}$, the biobutanol yield was decrease with the increasing of inoculum size. This interaction shows that incubation temperature at $32^{\circ} \mathrm{C}$ is more favorable temperature for the fermentation compared to $42^{\circ} \mathrm{C}$.

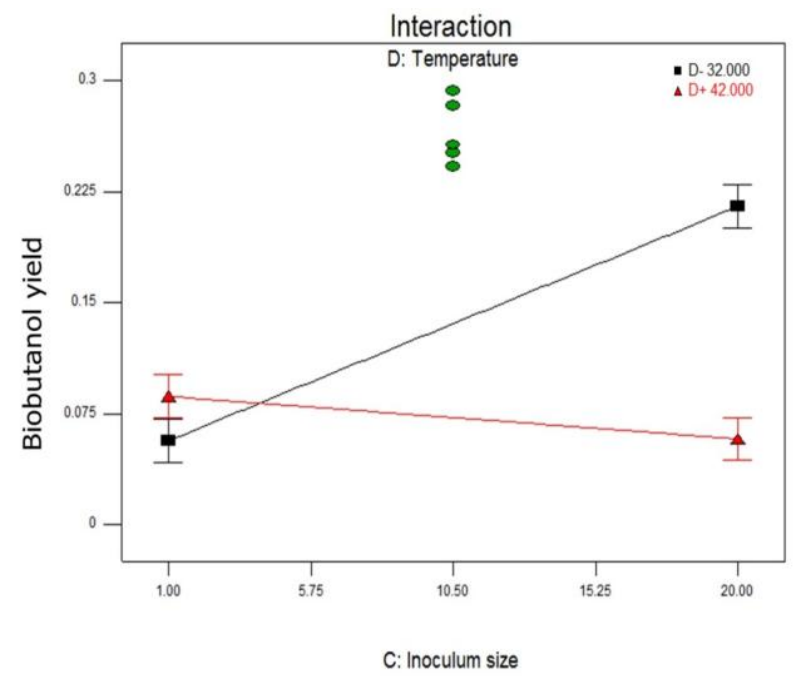

Figure 1: The interaction graph between factor C, inoculum size and factor D, temperature.

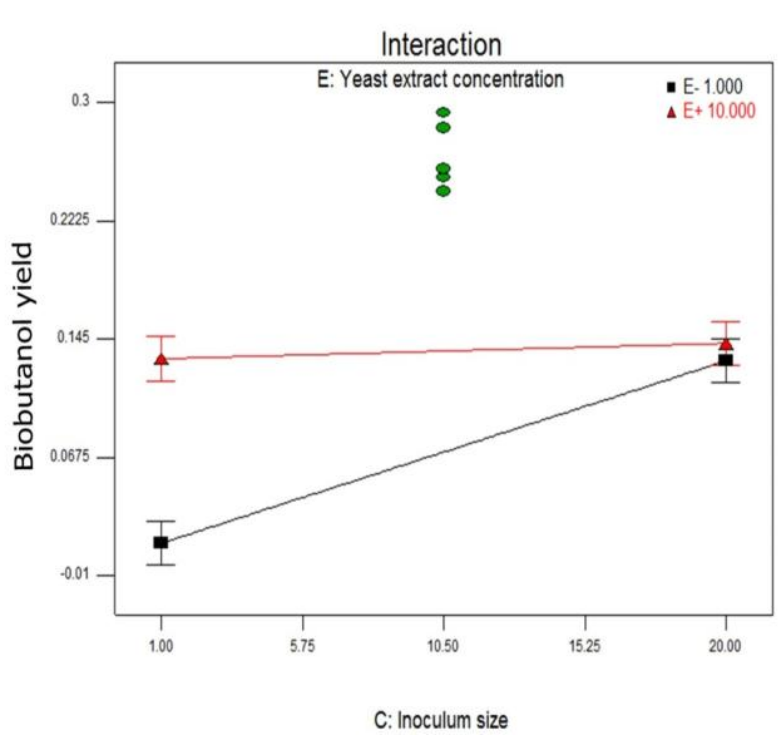

Figure 2: The interaction graph between factor $\mathrm{C}$, inoculum size and factor $\mathrm{E}$, yeast extract concentration.

The interaction between inoculum size and yeast extract concentration can be found in Figure 2. The biobutanol yield seems not affected by inoculum size when the yeast extract concentration $10 \mathrm{~g} / \mathrm{L}$. Otherwise, at $1 \mathrm{~g} / \mathrm{L}$ of yeast extract, the biobutanol yield is increasing gradually when inoculum size increased. This is due to the high concentration of yeast extract was stimulated the growth of the cells, but reduced the ability to produce solvents. ${ }^{8}$

\section{Validation of experiment}

In order to verify the experiment, two runs of validation experiment were performed which one of them is at the best conditions based on the highest production of biobutanol from Table 2 and the other one experiment derived by the solution given by Design Expert analysis. The results obtained were then compared to the value of response predicted by the regression model. From the data in Table 5, the percentage error was calculated as low as $5.87 \%$ for Run 1 and $10.09 \%$ for Run 2. This indicates the factors that contribute to the biobutanol production analyzed by the model are valid to be used. 


\section{Chemical Engineering Research Bulletin 19(2017) 36-42}

Table 5: Validation runs of experiment.

\begin{tabular}{|c|c|c|c|c|}
\hline \multirow{2}{*}{ Run } & \multirow{2}{*}{ Conditions } & \multicolumn{2}{|c|}{$\begin{array}{l}\text { Biobutanol } \\
\text { yield }(\mathrm{g} / \mathrm{g})\end{array}$} & \multirow{2}{*}{$\begin{array}{c}\text { Error } \\
(\%)\end{array}$} \\
\hline & & $\begin{array}{c}\text { Predic } \\
\text { ted }\end{array}$ & $\begin{array}{l}\text { Experi } \\
\text { mental }\end{array}$ & \\
\hline 1 & $\begin{array}{l}\mathrm{pH} 6 \\
\text { Total } \\
\text { sugars } \\
\text { concentration } \\
50 \mathrm{~g} / \mathrm{l} \\
\text { Inoculum } \\
\text { size } 10.5 \% \\
\text { Temperature } \\
37^{\circ} \mathrm{C} \\
\text { Yeast extract } \\
5 \mathrm{~g} / \mathrm{l}\end{array}$ & 0.2930 & 0.2758 & 5.87 \\
\hline 2 & $\begin{array}{l}\mathrm{pH} 5 \\
\text { Total sugars } \\
\text { concentration } \\
40 \mathrm{~g} / \mathrm{l} \\
\text { Inoculum } \\
\text { size } 20 \% \\
\text { Temperature } \\
32^{\circ} \mathrm{C} \\
\text { Yeast extract } \\
9.75 \mathrm{~g} / \mathrm{l}\end{array}$ & 0.2565 & 0.2306 & 10.09 \\
\hline
\end{tabular}

\section{Conclusion}

From this study, it is to be concluded that the main factors affect for biobutanol production from OPF juice by $C$. acetobutylicum ATCC 824 are yeast extract concentration, inoculum size and temperature with value $8.20 \%, 7.84 \%$ and $7.56 \%$, respectively. The least affecting factors are total sugars in OPF juice and $\mathrm{pH}$ with $2.09 \%$ and $0.78 \%$, respectively. The highest contribution of interaction between inoculum size and yeast extract concentration as high as $16.31 \%$ proved that these factors are the most important factors in the $\mathrm{ABE}$ fermentation.

\section{Acknowledgement}

The authors are grateful to Universiti Malaysia Pahang for financial support (grant numbers RDU140139).

\section{References}

1. N. Qureshi, T. C. Ezeji, J. Ebener, B. S. Dien, M. A. Cotta and H. P. Blaschek, "Butanol production by Clostridium beijerinckii. Part 1: Use of acid and enzyme hydrolyzed corn fiber," Bioresource Technology, vol. 99, no. 13, pp. 5915-5922, 2008.

2. Y. Tashiro and K. Sonomoto, "Advances in butanol production by clostridia," Current research, technology and education in Applied
Microbiology Biotechnology, vol. 2, no.2, pp. 1383-1394, 2010.

3. F. Raganati, S. Curth, P. Gotz, G. Olivieri and A. Marzocchella, "Butanol production from lignocellulosic-based hexoses and pentoses by fermentation of Clostridium acetobutylicum," Chemical engineering transaction, vol. 27, pp. 9196, 2012.

4. D. T. Jones and D. R. Woods, "Acetone-butanol fermentation revisited," Microbiological reviews, vol. 50, no. 4, pp. 484-524, 1986.

5. M. A. K. M. Zahari, M. R. Zakaria, H. Ariffin, M. N. Mokhtar, J. Salihon, Y. Shirai and M. A. Hassan, "Renewable sugars from oil palm frond juice as an alternative novel fermentation feedstock for value-added products," Bioresource Technology, vol. 110, pp. 566-571, 2012.

6. H. Shukor, N. K. N. Al-Shorgani, P. Abdeshahian, A. A. Hamid, N. Anuar, N. A. Rahman and M. S. Kalil, "Production of butanol by Clostridium saccharoperbutylacetonicum $\mathrm{N} 1-4$ from palm kernel cake in acetone-butanol-ethanol fermentation using an empirical model ," Bioresource Technology, vol. 170, pp. 565-573, 2014.

7. I. Komonkiat and B. Cheirsilp, "Felled oil palm trunk as a renewable source for biobutanol production by Clostridium spp.," Bioresource Technology, vol. 146, pp. 200-207, 2013.

8. 8.M. N. A. Razak, M. F. Ibrahim, P. L. Yee, M. A. Hassan and S. A. Aziz, "Statistical optimization of biobutanol production from oil palm decanter cake hydrolysate by Clostridium acetobutylicum ATCC 824 ," Bioresource, vol. 8, no. 2, pp. 1758-1770, 2013.

9. N. K. N. Al-Shorgani, H. Shukor, P. Abdeshahian, M. Y. M. Nazir, M. S. Khalil, A. A. Hamid, and W. M. W. Yusoff, "Process optimization of butanol production by Clostridium saccharoperbutylacetonicum N1-4 (ATCC 13564) using oil palm mill effluent in acetone-butanolethanol fermentation," Biocatalysis and Agricultural Biotechnology, vol. 4, pp. 244-249, 2015.

10. A. Ranjan and R. Mayank, "Development of semidefined rice straw-based medium for butanol production and its kinetic study," Biotech, vol. 3, no. 5, pp. 353-364, 2013.

11. E. I. Khamaiseh, M. S. Kalil, O. Dada, I. E. Shawabkeh and W. M. W. Yusoff, "Date fruit as carbon source in RCM-modified medium to produce biobutanol by Clostridium acetobutylicum NCIMB 13357," Journal of Applied Sciences, vol. 12, no. 11, pp. 1160-1165, 2012.

12. E. I. S. Khamaiseh, A. A. Hamid, W. M. W. Yusoff and M. S. Kalil, "Effect of some environmental parameters on biobutanol 


\section{Chemical Engineering Research Bulletin 19(2017) 36-42}

production by Clostridium acetobutylicum NCIMB 13357 in date fruit medium," Pakistan
Journal of Biological Sciences, vol. 16, no. 20, pp. 1145-1151, 2013.

\section{Available online at http://www.banglajol.info/index.php/CERB}

